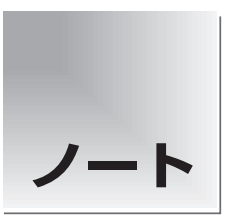

論文受付 2010年 5 月24日

論文受理

2011 年 4 月25日

Code No. 261

\subsection{T と 3 T におけるスピンエコー法の クロストークの影響に関する検討}

\author{
梶迫正明 ${ }^{1,2)}$ ・宮地利明 ${ }^{2)} \cdot$ 谷口正洋 $^{1)} \cdot$ 赤土裕子 ${ }^{3)}$ \\ 小泉幸司 ${ }^{1)}$ ・平賀 顯 $^{1)} \cdot$ 三木幸雄 ${ }^{4}$ \\ 1 ) 京都大学医学部附属病院放射線部 \\ 2)金沢大学大学院医学系研究科 \\ 3) 医療法人社団亮人会那須中央病院放射線部 \\ 4) 大阪市立大学大学院医学研究科
}

\section{緒 言}

$3 \mathrm{~T}$ の magnetic resonance imaging(MRI)の脳の撮像 において, $\operatorname{spin-echo}(\mathrm{SE})$ 法の $\mathrm{T}_{1}$ 強調像は, 白質と灰 白質のコントラストが低下するといわれている。これ には $\mathrm{T}_{1}$ 值の延長が原因であるとの報告がある ${ }^{1 \sim 3)}$ 。し かし，このコントラスト低下は， $\mathrm{T}_{1}$ 值の延長だけでな く magnetization transfer effect(MT効果)とクロス トークが影響する可能性を示した報告がある4).この MT 効果とクロストークにおいて，3 T での MT 効果が コントラストに及ぼす影響に関しての報告がある5)。ま た $3 \mathrm{~T}$ でクロストークの影響を考慮した撮像により白 質と灰白質のコントラストノイズ比が改善するという 報告がある6)。過去の報告4, 6)では，コントラストノイ
ズ比での評価であるが，1.5 T と $3 \mathrm{~T}$ といった静磁場 強度の違いによる評価ではノイズレベルが異なってく るので，ノイズの影響があるコントラストノイズ比よ りもコントラストのみのほうが正確に評価することが できる。また，どの程度のスライス間隔で $1.5 \mathrm{~T}$ と $3 \mathrm{~T}$ との違いが現れるかといった詳細なクロストークの静 磁場強度の違いによる影響の検討はなされていない.

そこで，われわれはファントムを用いて $1.5 \mathrm{~T}$ と $3 \mathrm{~T}$ におけるクロストークの画像コントラストに与える影 響を解明するために，最初にスライスプロファイルと その半值幅(full width at half maximum; FWHM)の測 定を行い,さらにFWHM の違いが画像コントラスト にどのように関与するかを健常ボランティアの脳を撮

\title{
Evaluation of Crosstalk Effect on Spin-echo Images at 1.5 and $3 \mathrm{~T}$
}

\author{
Masaaki Kajisako,, 2) Tosiaki Miyati,,2) Masahiro Taniguchi,," Yuko Syakudo,, \\ Koji Koizumi, ${ }^{1)}$ Akira Hiraga, ${ }^{1)}$ and Yukio Miki ${ }^{4}$ \\ 1) Department of Radiology, Kyoto University Hospital \\ 2) Division of Health Science, Kanazawa University Graduate School of Medical Sciences \\ 3) Department of Radiology, Nasu Central Hospital \\ 4) Osaka City University Graduate School of Medicine
}

Received May 24, 2010; Revision accepted April 25, 2011; Code No. 261

\section{Summary}

The purpose of this study is to evaluate the crosstalk effect on spin-echo (SE) images at 1.5 and $3 \mathrm{~T}$ MRI. We examined the influence of crosstalk by comparing the full width at half-maximum (FWHM) and slice profile of images of a wedge-shaped phantom for various slice gaps. We also assessed crosstalk effect in the brain by comparing image contrast among healthy volunteers $(n=8)$. Among the subjects, the shapes of the slice profiles at $1.5 \mathrm{~T}$ were similar to those at $3 \mathrm{~T}$ for long repetition times (TRs); however, at shorter TRs, differences in slice profiles were observed among the subjects and were more apparent at 3 than at 1.5 $\mathrm{T}$. The relative contrast between white matter and gray matter on $\mathrm{T}_{1}$-weighted images was lower at 3 than at 1.5 T. The crosstalk effect was strongest when the TR of the excitation pulse was short. The influence of the adjacent excitation pulse is important in the process of $T_{1}$ relaxation because $T_{1}$ values are greater at $3 \mathrm{~T}$. In conclusion, the influence of crosstalk on $\mathrm{SE} \mathrm{T}_{1}$-weighted images is greater at 3 than at $1.5 \mathrm{~T}$.

Key words: crosstalk, spin-echo, magnetic resonance imaging (MRI), 3.0 Tesla, 1.5 Tesla

別刷資料請求先：干 606-8507 京都府京都市左京区聖護院川原町 54 
像して検討した。

\section{1. 方 法}

\section{1-1 使用機器}

MR 装置はSiemens 社製の MAGNETOM Avanto 1.5T(ver:syngo MR B15) と MAGNETOM Trio a Tim System 3T(ver:syngo MR B15)を用いた. $1.5 \mathrm{~T}$ と $3 \mathrm{~T}$ とも最大傾斜磁場強度は $45 \mathrm{mT} / \mathrm{m}$, 最大スリュー レートは $200 \mathrm{~T} / \mathrm{m} / \mathrm{s}$ である。またコイルは $12 \mathrm{ch}$ head matrix coil(ファントム撮影時)と全身用送受信コイル (健常ボランティア撮像時)を使用した。

健常ボランティアは 8 名(年齢 $22 \sim 29$ 歳, 平均年 齢 $25.7 \pm 2.6$ 歳, 男性 6 名, 女性 2 名) において行っ た。また本研究の目的抢よび意義について, 自由意志 に基づいている点や利益相反はない点などを詳細に 説明し同意を得た後，本研究を行った。

\section{1-2 ファントムの撮像方法}

MRI ファントム 90-401 型(日興ファインズ工業株 式会社)に備えてある対向くさびファントムを, 繰り 返し時間 (repetition time; TR) とスライス間隔を変え て撮像した，撮像断面は横断面とし，ガントリー中心 にMRI ファントムを配置した。

ファントムの撮像条件については，SE 法を使用し 撮像視野(field of view; FOV)256×256 mm，マトリクス 512×512，TR 500〜5000 ms，エコー時間（echo time; TE) $9.3 \mathrm{~ms}$, スライス厚 $5 \mathrm{~mm}$, 撮像加算回数 3 または 12 , 分割回数を 1, 受信バンド幅 $217 \mathrm{~Hz} /$ ピクセル，スラ イス励起方法は sequential とした. Radio frequency $(\mathrm{RF})$ パルスの印加時間は $1.5 \mathrm{~T}$ と $3 \mathrm{~T}$ とも 90 度パル スで $2.048 \mathrm{~ms}, 180$ 度パルスで $2.560 \mathrm{~ms}$ とした。 ス ライス枚数は $1 ， 3$ とした。 スライス間隔はこれらスラ イス枚数に打いて $0 \mathrm{~mm}(0 \%), 0.5 \mathrm{~mm}(10 \%), 1 \mathrm{~mm}$ (20\%), $2 \mathrm{~mm}(40 \%), 4 \mathrm{~mm}(80 \%), 10 \mathrm{~mm}(200 \%)$ とした。また $3 \mathrm{~T}$ の長い TRに打いてスライス枚数 $1 ， 5 ， 13$ とスライス間隔 $0.5 \mathrm{~mm}(10 \%), 10 \mathrm{~mm}$ (200\%)の組み合わせの条件でも撮像を行った。

米国電気製造者協会 (National Electrical Manufacturers Association; NEMA)基準によるスライス厚測定 試験の TR は測定物質の $\mathrm{T}_{1}$ 值の 3 倍以上と規定され ている7). ファントム素材である $80 \%$ PVA ゲルの $\mathrm{T}_{1}$ 值は $1.5 \mathrm{~T}$ が $940 \mathrm{~ms}, 3 \mathrm{~T}$ が $1130 \mathrm{~ms}$ であったので TRを $1.5 \mathrm{~T}$ で $4000 \mathrm{~ms}$ と $3 \mathrm{~T} て ゙ 5000 \mathrm{~ms}$ に設定した $\left(\mathrm{TR} / \mathrm{T}_{1}>4\right)$ ．また頭部の $\mathrm{T}_{1}$ 強調像を想定して，短い $\mathrm{TR}$ の検討においては， $\mathrm{T}_{1}$ 值から同一の $\mathrm{TR} / \mathrm{T}_{1}$ となる ように, $1.5 \mathrm{~T}$ で $500 \mathrm{~ms}$ と $3 \mathrm{~T}$ で $600 \mathrm{~ms}$ に設定した $\left(\mathrm{TR} / \mathrm{T}_{1} \doteqdot 0.53\right)$.

\section{1-3 ファントムの解析方法}

ファントム撮像に打けるFWHM とスライスプロ ファイルの測定は, NEMA 基準のスライス厚測定試 験7,8)に基づいて行った。これによって得られたファ ントム画像のくさび板に $25 \times 150$ ピクセルの領域を設 定し, 各列 (25ピクセル)の平均信号強度を求めた。 次に設定領域の隣接したピクセルの差分值をプロッ トし，スライスプロファイルを得た．次に互い違いに なっているくさび板の FWHM から回転補正を行っ た。また $1.5 \mathrm{~T} と 3 \mathrm{~T}$ のスライスプロファイルの形状 の比較のためにピーク值で正規化を行った。この際 スライスプロファイルにはノイズが多く含まれてお り，観察しやすくするため高周波遮断によるノイズ除 去を行った。処理は二次バターワース特性をもつ low pass フィルタのノイズ除去を行った。

シングルスライスの $\mathrm{FWHM}\left(F W H M_{\mathrm{ss}}\right)$ と信号強度 $\left(S I_{\mathrm{ss}}\right)$ を基準として，マルチスライスに抏いてスライ ス間隔を変化させた時の $\mathrm{FWHM}\left(F W H M_{\mathrm{ms}}\right)$ と信号強 度 $\left(S I_{\mathrm{ms}}\right)$ の減少率 $R R_{\mathrm{FWHM}}$ (Reduction Rate FWHM $_{\text {F }}$ ) と $R R_{\mathrm{SI}}\left(\right.$ Reduction Rate $\left._{\mathrm{SI}}\right)$ を式(1)，(2)から計算した。

$$
R R_{\mathrm{FWHM}}=F W H M_{\mathrm{ms}} / F W H M_{\mathrm{ss}}
$$

$$
R R_{\mathrm{SI}}=S I_{\mathrm{ms}} / S I_{\mathrm{ss}}
$$

ファントム撮像は 5 回行い, $R R_{\mathrm{FWHM}}$ と $R R_{\mathrm{SI}}$ の平均 值を求めた.

\section{1-4 健常ボランティアの撮像方法}

撮像条件は, SE 法の $\mathrm{T}_{1}$ 強調像を, FOV 179×220 mm, マトリクス $208 \times 256$, TR 500/600 ms $(1.5$ T/3 T), TE $9.3 \mathrm{~ms}$, スライス厚 $4 \mathrm{~mm}$, 撮像加算回数 1 , 分割回 数を 1, 受信バンド幅 $217 \mathrm{~Hz} /$ ピクセル，スライス 励起方法を sequential とした。 スライス枚数は 1,3 とした。 スライス間隔はこれらスライス枚数において $0 \mathrm{~mm}(0 \%), 0.4 \mathrm{~mm}(10 \%), 0.8 \mathrm{~mm}(20 \%), 1.2 \mathrm{~mm}$ (40\%)，3.2 mm(80\%)とした。スライス面は anterior commissure と posterior commissure を結ぶラインに 平行な基底核レベルの横断面とした。

TR の設定については， $\mathrm{Lu}$ ら $^{9}$ は $1.5 \mathrm{~T}$ と $3 \mathrm{~T}$ の前頭 葉の白質と灰白質の $T_{1}$ 值を測定しており, 前頭葉白質 の $\mathrm{T}_{1}$ 值は $1.5 \mathrm{~T}$ にて $556 \pm 20 \mathrm{~ms}, 3 \mathrm{~T}$ にて $699 \pm 38 \mathrm{~ms}$, また灰白質の $\mathrm{T}_{1}$ 值は $1.5 \mathrm{~T}$ にて $1048 \pm 61 \mathrm{~ms}, 3 \mathrm{~T}$ にて $1209 \pm 109 \mathrm{~ms}$ と報告している。この值からファントム 実験と同様に $1.5 \mathrm{~T}$ で $500 \mathrm{~ms}$ と $3 \mathrm{~T}$ で $600 \mathrm{~ms}$ に設 定した。

\section{1-5 健常ボランティアの解析方法}

健常ボランティア 8 名に执いて, 脳の撮像を行い 


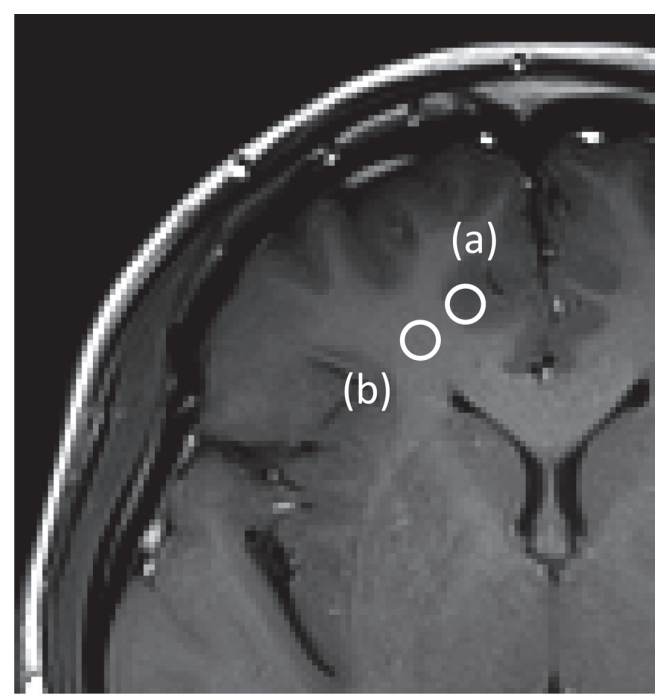

Fig. 1 Setting the regions of interest (ROIs). The positioning for gray matter (a) and white matter (b) is indicated by the white circles.

前頭葉の白質と灰白質に関心領域(region of interest; ROI，平均 20 pixel）を設定し信号強度を測定した (Fig. 1)。これらの信号強度からコントラスト (Contrast $\left._{\mathrm{WM}-\mathrm{GM}}\right)$ を以下の式(3)で求めた.

$$
\text { Contrast }_{\mathrm{WM}-\mathrm{GM}}=\left(S I_{\mathrm{WM}}-S I_{\mathrm{GM}}\right) /\left(S I_{\mathrm{WM}}+S I_{\mathrm{GM}}\right)
$$

$S I_{\mathrm{WM}}$ は白質の信号強度, $S I_{\mathrm{GM}}$ は灰白質の信号強度 である。また, シングルスライスのコントラスト (Contrast $_{\mathrm{ss}}$ )を基準として, マルチスライスでスライス間隔 を変化させたときのコントラスト $\left(\right.$ Contrast $\left._{\mathrm{ms}}\right)$ の変化 relative contrast $(R C)$ を式(4)により計算した。

$$
R C=\text { Contrast }_{\mathrm{ms}} / \text { Contrast }_{\mathrm{ss}}
$$

$1.5 \mathrm{~T}$ と $3 \mathrm{~T}$ の $R C$ についての有意差検定は, 有意水 準を 5\%とした Wilcoxon signed-rank test で比較した。

\section{2. 結 果}

\section{2-1 ファントムにおける検討}

長い $\mathrm{TR}$ では, $1.5 \mathrm{~T}$ と $3 \mathrm{~T}$ とスライス間隔の違 いによってスライスプロファイルに変化はなかった (Fig. 2).

一方， $\mathrm{T}_{1}$ 強調像を想定した短い $\mathrm{TR}$ では, $1.5 \mathrm{~T}$ と $3 \mathrm{~T}$ ともに, スライス間隔が $0 \%$ の時に最もスライス プロファイルが狭くなりスライス間隔をあけるにつれ てスライスプロファイルが広がり, 1 スライスで最大 となった(Fig. 3，4)。RR FWнм は $1.5 \mathrm{~T}$ では, スライス 間隔が $0 \%, 10 \%, 20 \% ， 40 \% ， 80 \%$ の順で 0.842 , $0.918 ， 0.978 ， 0.995,0.992$ となり，3 Tでは 0.804, $0.844,0.916,0.981,0.989$ となった. すべてのスラ
$1.5 \mathrm{~T}, \mathrm{TR}=4000 \mathrm{~ms} ; 3 \mathrm{~T}, \mathrm{TR}=5000 \mathrm{~ms}$

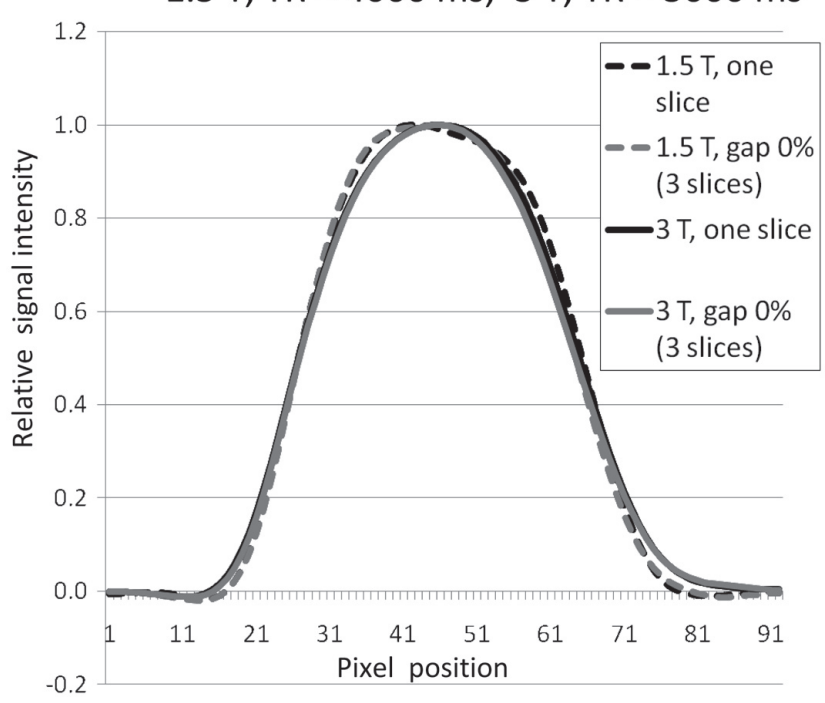

Fig. 2 Slice profiles at 1.5 and $3 \mathrm{~T}$ for a long TR.

イス間隔において $3 \mathrm{~T}$ のほうが $R R_{\mathrm{FWHM}}$ は小さくなっ た(Fig. 5)。 $R R_{\mathrm{SI}}$ は $1.5 \mathrm{~T}$ では, スライス間隔が $0 \%$, $10 \%, 20 \%, 40 \%, 80 \% の$ 順で $0.785,0.833$, $0.889,0.953,0.982$ となり, $3 \mathrm{~T}$ では $0.779,0.836$, $0.882 ， 0.947 ， 0.981$ となり $R R_{\mathrm{SI}}$ に違いは認められな かった。またスライス間隔が $80 \%$ と $200 \%$ とでは FWHM に変化はなく, 信号強度は $1 \%$ 程度の違いが あった。

$3 \mathrm{~T}$ において長い TR でスライス間隔 10\%では, マ ルチスライス枚数が 5 の場合 $\left(R R_{\mathrm{FWHM}}: 0.948\right)$ よりも 13 の場合 $\left(R R_{\mathrm{FWHM}}: 0.877\right)$ のほうが, スライスプロ ファイルは狭くなった(Fig. 6a)。この条件下で，スラ

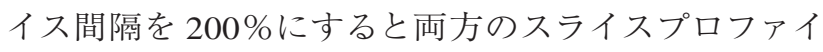
ルは同様な形状を示した(Fig. 6b)。ファントム素材であ る $80 \%$ PVA ゲルの信号強度は, スライス枚数 1，3， 5, 13 の順に3061 $\pm 12.3,3054.5 \pm 11.3,3058.5 \pm 12.7$, $3044.7 \pm 14.5$ となった。

\section{2-2 健常ボランティアにおける検討}

健常ボランティアに打ける脳前頭葉の白質と灰白

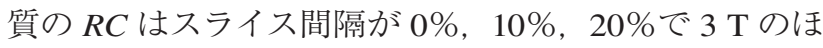
うが $1.5 \mathrm{~T}$ より $R C$ は有意に低下した(Table 1). $1.5 \mathrm{~T}$ と $3 \mathrm{~T}$ で撮像した脳の 1 スライスの画像と 3 スライス でスライス間隔が $0 \%$ の画像を Fig. 7 に示す.

\section{3. 考 察}

$\mathrm{T}_{1}$ 強調像を想定した短い $\mathrm{TR}$ では, $3 \mathrm{~T}$ のほうが $1.5 \mathrm{~T}$ と比べてスライス間隔が小さい時の $R R_{\mathrm{FWHM}}$ が 大きく, $3 \mathrm{~T}$ ではスライス間隔が小さくなるにつれて スライスプロファイルの形状が狭くなっていた，特に 


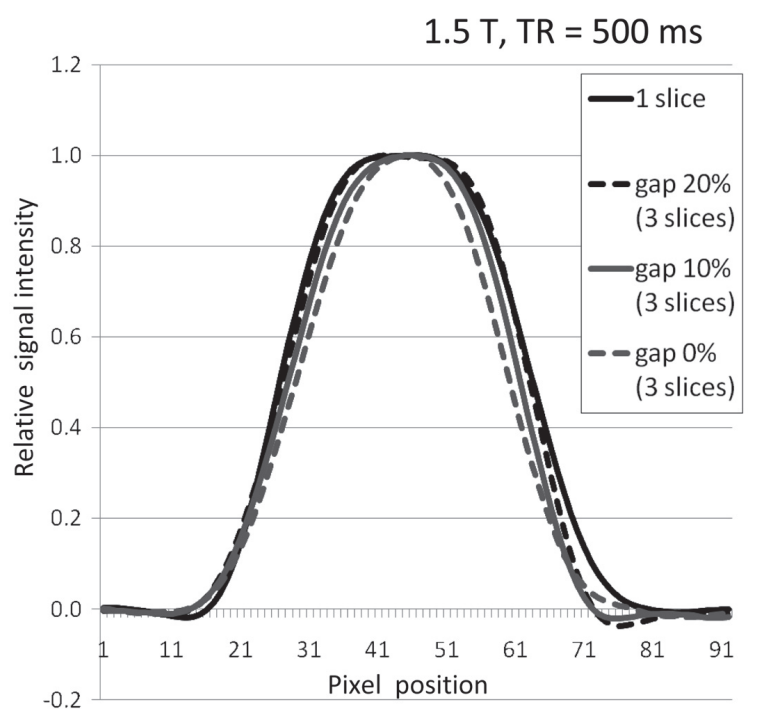

Fig. 3 Slice profiles for various slice gaps at $1.5 \mathrm{~T}$ (TR=500 ms).

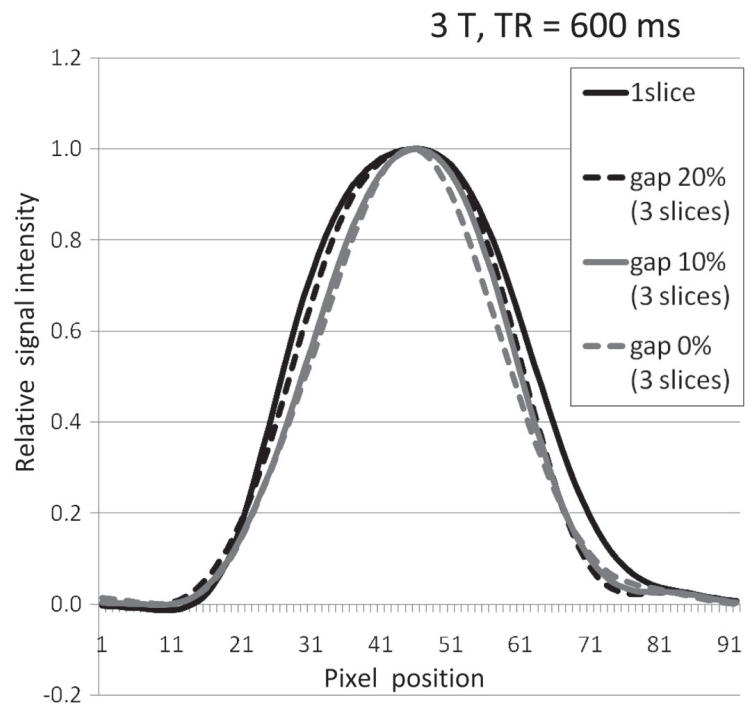

Fig. 4 Slice profiles for various slice gaps at $3 \mathrm{~T}$ (TR=600 ms)

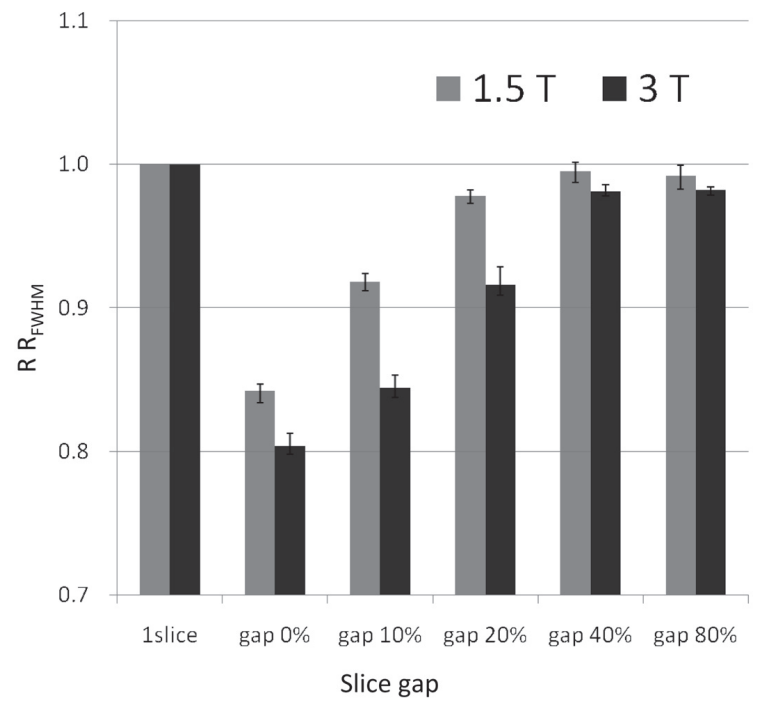

Fig. 5 Relationship between slice gap and reduction ratio of FWHM at 1.5 and $3 \mathrm{~T}$.
$3 \mathrm{~T}, \mathrm{TR}=5000 \mathrm{~ms} ;$ slice gap $=10 \%$

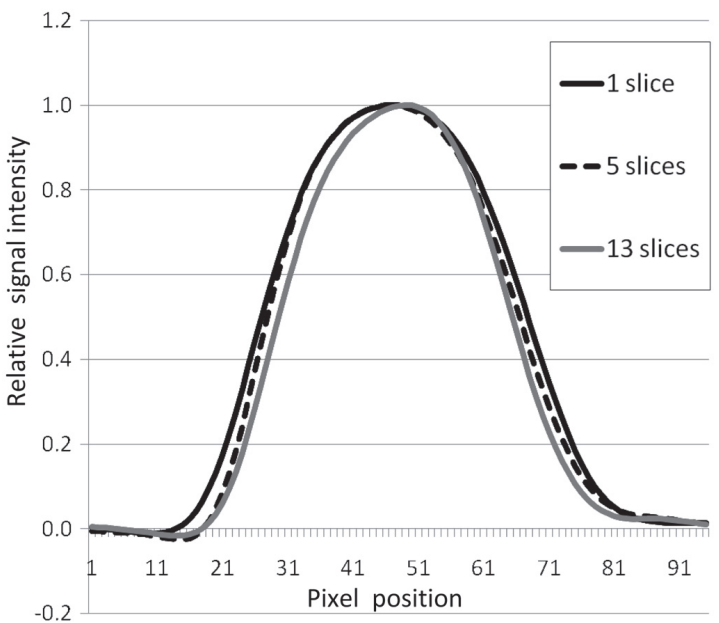

$3 \mathrm{~T}, \mathrm{TR}=5000 \mathrm{~ms} ;$ slice gap $=200 \%$

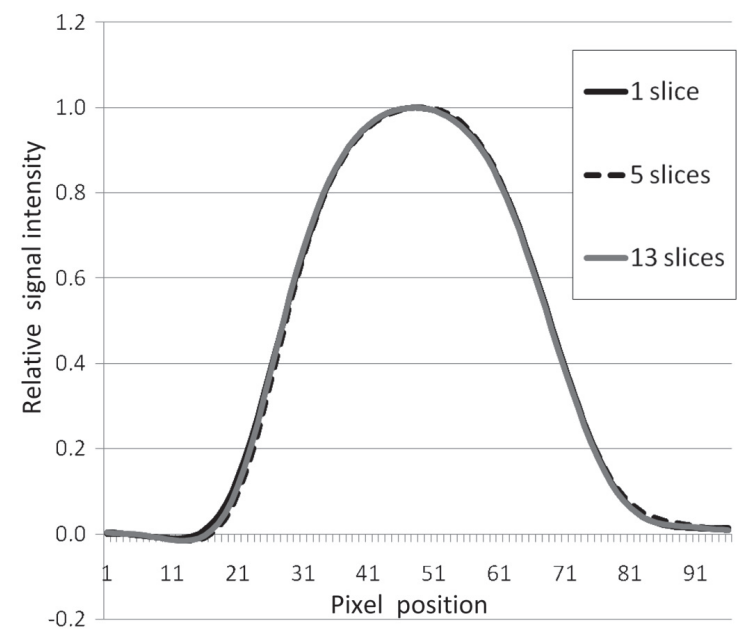

Fig. 6 Slice profiles for various numbers of a slices at $3 \mathrm{~T}$.

(a) $\mathrm{TR}=5000 \mathrm{~ms}$; slice gap $=10 \%$.

(b) $\mathrm{TR}=5000 \mathrm{~ms}$; slice gap $=200 \%$.

スライス間隔が $20 \%$ 以下で $3 \mathrm{~T}$ のほうがクロストーク の影響が大きいことが明らかになった。また長い TR ではスライス間隔による $R R_{\mathrm{FWHM}}$ の影響が少ないこと からクロストークの影響はほとんどないことが判明し た。しかし，この際マルチスライス枚数を増加させる と，スライスプロファイルが狭まった(Fig. 6a).これ らのことから長い TRの時でも, マルチスライスのよ うに励起パルスを与える時間間隔が短いときに, 十分 に縦磁化が回復する前に次の励起パルスの影響に よって信号強度が低下すると考える。この際, 縦磁 化の回復は $\mathrm{T}_{1}$ 值の長い $3 \mathrm{~T}$ のほうが遅いので, 結果 的に $3 \mathrm{~T}$ が $1.5 \mathrm{~T}$ よりもクロストークの影響が大きく なると考えられる. Kasahara ら6)も $3 \mathrm{~T}$ のクロストー クが大きくなる原因として $\mathrm{T}_{1}$ 值の延長の影響を示唆 しており，筆者の見解と一致する. スライス枚数の増 
Table 1 Change in relative image contrast with various slice gaps at 1.5 and $3 \mathrm{~T}$

\begin{tabular}{lccc}
\hline \hline & $\begin{array}{c}\text { Relative } \\
\text { contrast } \\
(1.5 \mathrm{~T})\end{array}$ & $\begin{array}{c}\text { Relative } \\
\text { contrast } \\
(3 \mathrm{~T})\end{array}$ & $\mathrm{P}$ value \\
\hline 1 slice & 1.000 & 1.000 & \\
3 slices - gap 0\% & 0.853 & 0.781 & $\mathrm{P}<0.05$ \\
3 slices - gap 10\% & 0.923 & 0.817 & $\mathrm{P}<0.05$ \\
3 slices - gap 20\% & 0.940 & 0.855 & $\mathrm{P}<0.05$ \\
3 slices - gap 40\% & 0.981 & 0.924 & $\mathrm{NS}$ \\
3 slices - gap 80\% & 0.989 & 0.960 & $\mathrm{NS}$ \\
\hline
\end{tabular}

NS, not significant

加により MT 効果も同時におこり両者の影響が考え られる。今回使用したファントムではスライス間隔 $200 \%$ にてスライス枚数を増加させたときのスライス プロファイルに変化がなかったが(Fig. 6b)，信号強 度はスライス枚数が 13 枚の時に若干減少傾向が見ら れた。 スライス枚数が $1 ， 3 ， 5$ 枚の範囲では信号強 度の違いは小さく、ファントム実験のクロストークの 影響の検討はスライス枚数 3 枚で行ったので MT 効 果の影響は小さいと考える。厳密にはスライス間隔を 変化させると MT 効果も変化すると考えられる，スラ イス間隔が $80 \%$ の時と $200 \%$ の時とで，信号強度の 違いは $1 \%$ 程度であり，ほぼ同じ值であった。これら のことから，スライス間隔の変化による MT 効果の影 響は小さくファントム実験の結果はクロストークの影 響を大きく示した結果であると推測する.

今回は $1.5 \mathrm{~T}$ と $3 \mathrm{~T}$ とで異なる $\mathrm{TR}$ を使用してい る. $\mathrm{T}_{1}$ 值の延長を考慮しても，な挍 $1.5 \mathrm{~T}$ と $3 \mathrm{~T}$ とで $R R_{\mathrm{FWHM}}$ が異なった。これはマルチスライスに扔ける 実際の励起パルスは TRよりも短い時間で印加され ているために $1.5 \mathrm{~T}$ と $3 \mathrm{~T}$ で差が発生したものと考え る.

一方，健常ボランティアに扔ける結果に扔いては， クロストークによるコントラストへの影響もファント ムでの検討同様に $3 \mathrm{~T}$ のほうが大きくなることが明ら かになった．しかし MT 効果の影響との切り分けは 既出の論文 ${ }^{4}$ 同様十分でない. $3 \mathrm{~T}$ の $\mathrm{SE}$ 法の $\mathrm{T}_{1}$ 強調 画像に打ける白質と灰白質のコントラストについて は， $\mathrm{Lu}$ ら $^{9)}$ により条件を最適にすればコントラストノ イズ比は $1.5 \mathrm{~T} よ り ~ 3 \mathrm{~T}$ のほゔ良いという報告があ る。しかし，これはシングルスライスでの検討であ り, クロストークの影響は検討されていない.また,

Fushimi ら ${ }^{4)}$ は, マルチスライスにて $1.5 \mathrm{~T}$ と $3 \mathrm{~T}$ にお ける白質と灰白質のコントラストノイズ比を比較して いる。これによるとスライス間隔を空ければ $3 \mathrm{~T}$ のほ

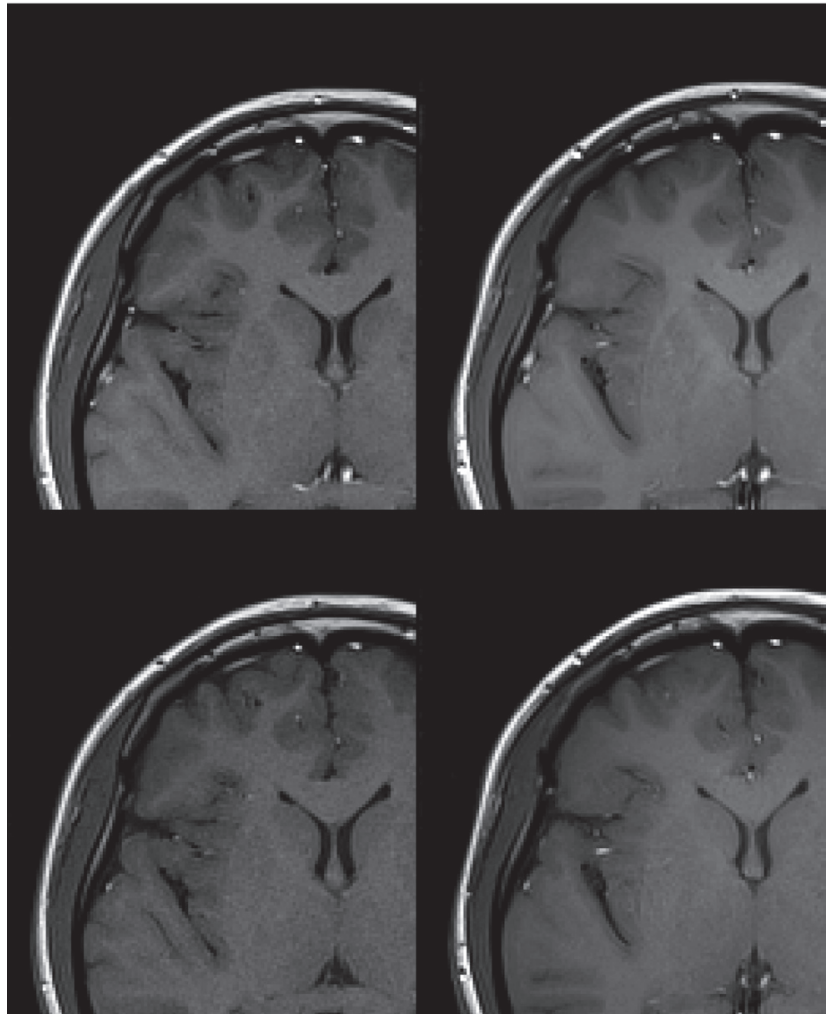

Fig. $7 \quad \mathrm{~T}_{1}$-weighted brain images obtained using one and three slices at 1.5 and $3 \mathrm{~T}$.

(a) $1.5 \mathrm{~T}$, one slice

(b) $1.5 \mathrm{~T}$, three slices, gap $=0 \%$.

(c) $3 \mathrm{~T}$, one slice.

(d) $3 \mathrm{~T}$, three slices, gap $=0 \%$.

うがコントラストノイズ比は良くなるという報告があ り，クロストークの影響が $3 \mathrm{~T}$ で大きくなるとしてい る.しかし，コントラストノイズ比は signal to noise ratio(SNR)の違いが影響しているため, $1.5 \mathrm{~T}$ と $3 \mathrm{~T}$ の本質的なクロストークの効果を比較するのは困難で ある、そこでわれわれは，コントラストノイズ比では なく相対的な画像コントラストで $1.5 \mathrm{~T}$ と $3 \mathrm{~T}$ の比較 を単純に行ったので，クロストークに与える因子をよ り正確にとらえていると考える。また藤原ら ${ }^{10)}$ も $3 \mathrm{~T}$ に扮ける研究にて， $3 \mathrm{~T}$ は $1.5 \mathrm{~T}$ と比較してクロス トークの影響を強く受けると考察しており，われわれ の結果と一致している。ただし，今回の健常ボラン ティアに拈ける検討では対象群の年齢が比較的若い 成人であったため, 他の年齢層や疾患群において本 事実が必ずしも当てはまらないかもしれない，検討対 象と人数を増やして詳細な解析を行う必要がある. また，RF 形状や測定位置によっても結果が異なる可 能性がある。ささらに，高速 SE 法はクロストークや前

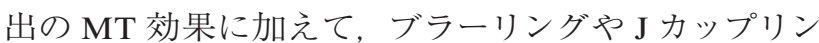
グなどがコントラストに影響を及ぼす11) ために本研究 のような解析はより複雑になると予想されるが，今後 
は高速 SE 法においても因子ごとの検討が必要であと 考える。

\section{4. 結 論}

$3 \mathrm{~T}$ の $\mathrm{SE}$ 法 $\mathrm{T}_{1}$ 強調像では $1.5 \mathrm{~T}$ よりもクロストー クの影響が大きくなることが示唆された。脳の SE 法

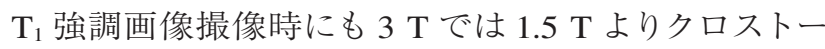
クの影響により脳実質のコントラストを大きく低下さ せる。

$3 \mathrm{~T}$ の装置ではこのことを念頭においてスライス間 隔を十分にとるか，分割回数を 2 以上に設定し交互
に撮像してクロストークの影響を考慮した検査を行う 必要がある。

\section{謝 辞}

本研究にあたり貴重なご助言をいただきました近 畿部会学術委員会論文塾運営委員の各位に誌面を借 りて御礼を述べさせていただく.

なお，本論文の一部は日本放射線技術学会第 65 回総会学術大会 (2009 年 4 月, 横浜) - 第 37 回秋季学 術大会 (2009 年 10 月, 岡山)にて発表した.

\section{参考文献}

1) Kuhl CK, Träber F, Schild HH. Whole-body high-fieldstrength (3.0-T) MR Imaging in Clinical Practice. Part I. Technical considerations and clinical applications. Radiology 2008; 246(3): 675-696.

2) Scarabino T, Nemore F, Giannatempo GM, et al. 3.0 T magnetic resonance in neuroradiology. Eur J Radiol 2003; 48(2): 154-164.

3) Ross JS. The high-field-strength curmudgeon. AJNR Am J Neuroradiol 2004; 25(2):168-169.

4) Fushimi Y, Miki Y, Urayama S, et al. Gray matter-white matter contrast on spin-echo T1-weighted images at $3 \mathrm{~T}$ and $1.5 \mathrm{~T}$ : a quantitative comparison study. Eur Radiol 2007; 17(11): 2921-2925.

5) Chang Y, Bae SJ, Lee YJ, et al. Incidental magnetization transfer effect in multislice brain MRI at 3.0T. J Magn Reson Imaging 2007; 25(4): 862-865.

6) Kasahara S, Miki Y, Mori N, et al. Spin-echo T1-weighted imaging of the brain with interleaved acquisition and presaturation pulse at $3 \mathrm{~T}$ : a feasibility study before clinical use. Acad Radiol 2009; 16(7): 852-857.

7) National Electric Manufacturers Association: Determination of slice thickness in diagnostic magnetic resonance images, NEMA Standard Publication, MS5(2003).

8) 土井 司。実際編 -6.2 スライス厚測定試験。臨床放射線 技術ハンドブック(上), 通商産業研究社, 1996: 468-472.

9) Lu H, Nagae-Poetscher LM, Golay X, et al. Routine clinical brain MRI sequences for use at 3.0 Tesla. J Magn Reson Imaging 2005; 22(1): 13-22.

10）藤原康博, 石森佳幸, 山口 功, 他. 3.0T MRI を用いた 高速 FLAIR 法における CSF artifact の抑制について。 日 放技学誌 2008; 64(12): 1513-1521.

11) Constable RT, Anderson AW, Zhong J, et al. Factors influencing contrast in fast spin-echo MR imaging. Magn Reson Imaging 1992; 10(4): 497-511.

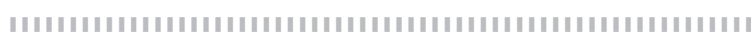

Fig. 1 関心領域 (ROI)の設定

白い円により (a) 灰白質と (b)白質の位置を示す.

Fig. 2 長い TR による $1.5 \mathrm{~T}$ と $3 \mathrm{~T}$ とのスライスプロファイル

Fig. $3 \quad 1.5 \mathrm{~T}$ に扔ける異なるスライス間隔でのスライスプロファイル $(\mathrm{TR}=500 \mathrm{~ms})$

Fig. $43 \mathrm{~T}$ に扔ける異なるスライス間隔でのスライスプロファイル $(\mathrm{TR}=600 \mathrm{~ms})$

Fig. $51.5 \mathrm{~T}$ と $3 \mathrm{~T}$ とのスライス間隔と FWHM の reduction ratio との関係

Fig. $63 \mathrm{~T}$ の異なるスライス枚数でのスライスプロファイル

(a) TR=5000 ms スライス間隔 $=10 \%$

(b) $\mathrm{TR}=5000 \mathrm{~ms}$ スライス間隔 $=200 \%$

Fig. $71.5 \mathrm{~T}$ と $3 \mathrm{~T}$ の 1 スライスと 3 スライスで得られた脳の $\mathrm{T}_{1}$ 強調画像
(a) $1.5 \mathrm{~T}$ のシングルスライス
(b) $1.5 \mathrm{~T}$ の 3 スライスでスライス間隔 $=0 \%$
(c) $3 \mathrm{~T}$ のシングルスライス
(d) $3 \mathrm{~T}$ の 3 スライスでスライス間隔 $=0 \%$

Table $1 \quad 1.5 \mathrm{~T}$ と $3 \mathrm{~T}$ との異なるスライス間隔での relative contrast の変化 